\title{
The diet of individuals: a study of a randomly-chosen cross section of British adults in a Cambridgeshire village
}

\author{
By SHEILA BINGHAM, N. I. MCNEIL AND J. H. CUMMINGS \\ MRC Dunn Clinical Nutrition Centre, Addenbrookes Hospital, Trumpington Street, \\ Cambridge CB2 $1 Q E$
}

(Received 20 March 1980 - Accepted 11 July 1980)

1. The dietary intakes of sixty-three adults, randomly-selected from the electoral role of a large village near Cambridge, have been measured using the weighed-intake technique for $7 \mathrm{~d}$.

2. Mean ( \pm SD) daily intakes (g) for men and women respectively were: energy (MJ) $10 \cdot 0 \pm 2 \cdot 4,8 \cdot 2 \pm 2 \cdot 1$; fat $104 \pm 27,90 \pm 27$; protein $77 \pm 20,67 \pm 16$; carbohydrate $285 \pm 81,229 \pm 74$; sucrose $91 \pm 47,57 \pm 33$.

3. When interviewed at the end of the study $\mathbf{4 0} \%$ of subjects said they were watching their weight.

4. Women ate less food over all than men, and proportionately less potato and bread, and used only one-third as much sugar in drinks, probably in an attempt to control their weight. Men took considerably more alcohol than the women. In the age-group 20-39 years alcohol provided $9 \%(1.0 \mathrm{MJ} / \mathrm{d})$ of the total energy intake in the men.

5. Wide variation in the intake of nutrients was observed amongst the individuals. For vitamin $\mathbf{C}$ and fibre intake this was partly explained by seasonal variation but for most nutrients total energy intake and food choice were the main determinants. The range of intakes of nutrients such as fat was similar in these individuals to that seen amongst countries internationally. It is suggested that if differences in nutrient intake amongst the various populations of the world can be associated with disease risk, then the same interpretation should be possible in individuals.

Dietary types and their composition vary widely amongst the various populations of the world. These differences in food intake have been related epidemiologically to the risk in a particular country of developing diseases such as cancer, bowel disorders and atherosclerosis (Armstrong \& Doll, 1975; Armstrong et al. 1975; Burkitt et al. 1972). Within countries there is also considerable variation in disease risk. In the UK mortality from heart disease, for example, varies between the sexes, amongst different age-groups and social classes (Department of Health and Social Security \& Medical Research Council, 1976; Office of Population Censuses and Surveys, 1978). However diet-associated risk factors are not normally related to individuals although differences in dietary intakes of individuals within a community are as great as differences between populations, and so contribute equally to individual risk.

The British National Food Survey (Ministry of Agriculture, Fisheries and Food, 1979) provides, annually, information on the food purchases of households. This information is useful for observing secular changes in food consumption and is a guide to the over-all diet of the population. Little is known about the diets of individuals, yet this is important in determining the risk of disease. Those dietary surveys of individuals which have been undertaken were concentrated on selected occupational groups (Morris et al. 1977), hospital patients or volunteers. We have therefore measured dietary intake in sixty-three adults, aged 20-80 years, engaged in a variety of occupations and living their usual lives in a Cambridgeshire village. To obtain a representative sample of the population, a random selection was made from the electoral register, and the subjects chosen were asked to record their dietary intakes by weighing all items of food and drink taken over 1 week.

The results show a wide range, often 5-fold or more, in the average daily intake of particular nutrients amongst this population over the week of study. 
METHODS AND SUBJECTS

A village (population 4500) 6 miles north of Cambridge was chosen for the study. It was compact and clearly-defined geographically, had well-developed local organisations, was largely the list of one family doctor, contained a typical selection of social classes, and was suitably close to the Dunn Nutrition Unit. Originally a market garden centre, since 1960 light industry had moved in and new housing estates had been built. The majority of the population found either local employment or in offices and professions in Cambridge.

The electoral register (which lists all residents aged 18 or over) of 2886 voters was used as the sampling frame for random selection of 103 people. After contacting local village officials a publicity campaign was mounted in the village. Every household was sent a letter explaining the study and posters were put up round the village. The selected subjects were divided into four groups geographically and individuals were then recruited. Over a period of 4 months each person was sent a personal letter inviting them to join in, followed by a visit to the house by one of the investigators.

The subjects were asked to weigh and record all individual items of food and drink and to weigh anything left over, for 1 week. Those who agreed to take part were visited by SB the day before they were due to start weighing their food, when an explanation and demonstration of the technique was given. The method of Widdowson (1936) was simplified so that the subjects were able to serve out their food on to their usual dishes or plates in the normal way. The weight of the plate and cumulative weights of the food added were recorded. Scales (Chatillon 0265) of large capacity, necessary to accommodate both the plate and the food, were obtained and the charts modified by CMS Weighing Ltd (London) to weight $4 \mathrm{lb}$ by $0.25 \mathrm{oz}$. After the subjects had repeated the demonstration successfully, the scales, pocket notebook, written instructions and examples of completed forms were left in the home. The subjects were visited on the first day of weighing to see that the technique had been understood. Further visits and instructions were made if necessary later in the week. The day after completion of the record, the subjects were revisited and the records thoroughly checked to ensure that all the necessary information had been recorded. In order not to interfere with normal eating habits, food bought away from home was not weighed but subjects were asked to describe the food eaten, its price and place of purchase. Samples of these foods were then bought and weighed. The number of drinks taken was recorded, subjects weighing an average cup or glass and the amount of drink, sugar or milk or both added. An average of four subjects per week were studied from May to August 1977.

Total daily energy and nutrient intakes were calculated by computer from food tables compiled for use in individual weighed surveys by The Department of Health and Social Security (DHSS; Disselduff et al. 1968). These tables incorporate average nutrient contents of cooked items of food and of dishes containing more than one ingredient for instance pies, stews, puddings, etc. from standard recipe books and food tables (Medical Research Council, 1945; McCance \& Widdowson, 1960). Cooking losses were obtained mainly by experiment. These tables have been modified (Bingham and Ravenscroft, unpublished results) to include dietary fibre and its components, measured by the method of Southgate (Southgate et al. 1976; Southgate, 1978). The subjects' own recipes were used where these differed from those in the DHSS tables.

On the first day of the study, height (without shoes) was measured using a Nivotoise portable height measure and body-weight (in indoor clothing) with a portable beam balance accurate to $100 \mathrm{~g}$ (CMS Weighing Ltd, London). Mid-arm biceps and triceps skinfold thicknesses were measured in triplicate using a Holtain skinfold caliper. Subjects were asked their age, occupation and details of smoking habits. Those who are designated as having weight problems in the results answered 'Yes' to the question 'Are you watching your 
weight?' during the course of a short interview (Bingham, Cummings and McNeil, unpublished results) at the final visit after completion of the survey.

Percentage body fat was calculated from skinfold thicknesses using the equations of Durnin \& Womersley (1974). An average weight for indoor clothes (without shoes) of $2.2 \mathrm{~kg}$ for men and $1.5 \mathrm{~kg}$ for women was subtracted from the measured weights in calculating the Quetelet index (weight without clothes and shoes/height; W/H $\left.\mathbf{H}^{2}\right)(\mathrm{D}$. R. R. Williams, personal communication; Department of Health and Social Security and Medical Research Council, 1976). Social class classification was based on occupation (Office of Population Censuses and Surveys, 1970). All results are expressed as mean \pm standard deviation.

\section{RESULTS}

\section{Subjects}

Of the 103 people chosen from the electoral register, eleven had either died or moved away. Sixty-three $(68 \%)$ of the remaining ninety-two agreed to weigh their food for 1 week. There were thirty-two men and thirty-one women. No significant differences were detected between the studied population in terms of age, sex or social class, and that of the general population as indicated by the Registrar General's Statistics (Bingham et al. 1979).

Co-operation rates were higher amongst the men $(82 \%)$, particularly in the younger age-groups. Most of the men were helped by the person responsible for food preparation, for instance the wife or mother. Rates were lowest amongst the 60-79 years age-range for women, two of whom were elderly and infirm. All subjects who took part found the technique of weighing easy to understand, and no subject was unable to complete the survey.

Twenty-five of the subjects (eleven men and fourteen women) claimed to have weight problems, of whom two were eating low-carbohydrate diets medically prescribed for diabetes, one was following a Weight Watchers' regimen, and one subject a low-energy diet for gallstones. Thirteen men and nine women smoked, average tobacco consumption for the whole group (sixty-three subjects) being thirty-two cigarettes and $0.2 \mathrm{oz}$ tobacco/person per week. Information on occupation was not obtained for two retired men; of the remaining thirty, sixteen were non-manual workers (social classes I, II, III $_{n}$ ) and fourteen manual workers (social classes $\mathrm{III}_{m}, \mathrm{IV}$ and V).

\section{Weight of food eaten}

The average weight of food eaten per day (excluding drinks) was $1277 \mathrm{~g}$ (Table 1 ). Women ate less meat, potatoes and bread than men, but more brown and wholemeal bread (women $23 \mathrm{~g}$, men $14 \mathrm{~g}$ ) and more cakes, puddings, biscuits, fruit and vegetables. Of the total average consumption of all sources of sucrose $(74.1 \pm 44.0 \mathrm{~g} / \mathrm{d}) 40 \%(31 \mathrm{~g})$ was taken as table sugar in drinks and on cereal. Men, however, consumed three times more table sugar than women (men $47 \mathrm{~g} / \mathrm{d}$, women $14 \mathrm{~g} / \mathrm{d}$ ).

Average consumption of beer for the whole group was $182 \mathrm{~g} / \mathrm{d}$ but virtually all was consumed by the men. Average daily intake of beer for men aged 20-39 years was $586 \mathrm{~g}$ (thirteen subjects), for the 40-59 years age-range $139 \mathrm{~g}$ (twelve subjects) and for the 60-79 years age-group $161 \mathrm{~g}$ (seven subjects).

Male non-manual workers ate less bread, sugar and separated fat than the manual workers, but more brown and wholemeal bread ( $20 \mathrm{~g}$ non-manual, $3 \mathrm{~g}$ manual), puddings, biscuits, cakes and meat, fruit and vegetables. The differences in potato and fish consumption between the two groups was largely accounted for by higher consumption of fried fish and chips by the manual workers (fried fish $16 \mathrm{~g}$ and chips $50 \mathrm{~g}$, manual workers; fried fish $5 \mathrm{~g}$, 


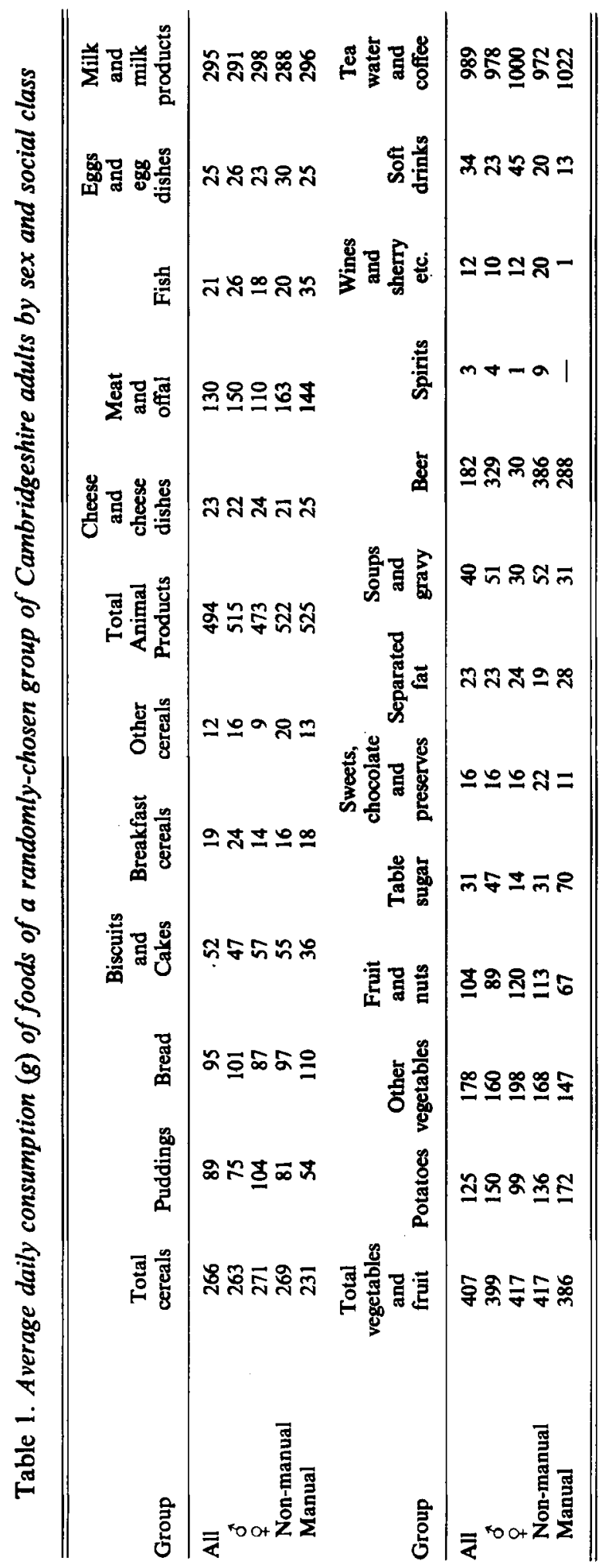


Table 2. Energy and nutrient intakes of a randomly-chosen group of Cambridge adults (Mean values and standard deviations; no. of subjects in parentheses)

\begin{tabular}{|c|c|c|c|c|c|c|c|c|}
\hline & & & \multicolumn{6}{|c|}{ Age group (years) } \\
\hline & \multicolumn{2}{|c|}{ Total } & \multicolumn{2}{|c|}{$20-39(13)$} & \multicolumn{2}{|c|}{$40-59(12)$} & \multicolumn{2}{|c|}{$60-79(7)$} \\
\hline & Mean & SD & Mean & SD & Mean & SD & Mean & SD \\
\hline & & & (a) $\mathrm{Me}$ & & & & & \\
\hline Energy (MJ) & $10 \cdot 02$ & $2 \cdot 41$ & $10 \cdot 23$ & 1.80 & $9 \cdot 86$ & 3.03 & $9 \cdot 90$ & $2 \cdot 57$ \\
\hline Protein (g) Animal & $51 \cdot 7$ & 16.9 & $50 \cdot 1$ & $18 \cdot 3$ & $51 \cdot 9$ & $17 \cdot 5$ & $54 \cdot 6$ & $15 \cdot 2$ \\
\hline Total & $77 \cdot 3$ & $20 \cdot 3$ & $77 \cdot 2$ & 19.9 & $77 \cdot 5$ & $23 \cdot 8$ & $77 \cdot 2$ & $17 \cdot 4$ \\
\hline Fat (g) & $104 \cdot 2$ & $27 \cdot 3$ & $105 \cdot 0$ & $24 \cdot 5$ & $102 \cdot 3$ & $30 \cdot 9$ & $105 \cdot 8$ & $29 \cdot 9$ \\
\hline Carbohydrate (g) & $285 \cdot 4$ & $81 \cdot 1$ & $279 \cdot 8$ & $61 \cdot 5$ & $284 \cdot 6$ & $99 \cdot 2$ & $297 \cdot 0$ & $90 \cdot 4$ \\
\hline Sucrose (g) & $91 \cdot 0$ & $47 \cdot 1$ & 83.8 & 38.8 & $87 \cdot 2$ & $46 \cdot 5$ & $111 \cdot 0$ & $62 \cdot 2$ \\
\hline Calcium (mg) & 902 & $34 \cdot 0$ & 934 & 290 & 827 & 414 & 974 & 307 \\
\hline Iron (mg) & $13 \cdot 0$ & 3.6 & $12 \cdot 5$ & $3 \cdot 2$ & $14 \cdot 1$ & $4 \cdot 5$ & $12 \cdot 1$ & $2 \cdot 4$ \\
\hline Vitamin A $(\mu \mathrm{g})$ & 1211 & 1200 & 1020 & 720 & 1479 & 1804 & 1105 & 666 \\
\hline Thiamin (mg) & $1 \cdot 11$ & 0.36 & $1 \cdot 12$ & 0.32 & 1.07 & 0.41 & $1 \cdot 17$ & 0.36 \\
\hline Riboflavin (mg) & 1.49 & 0.52 & 1.55 & 0.55 & 1.47 & 0.59 & $1 \cdot 40$ & 0.34 \\
\hline Nicotinic acid (mg) & $16 \cdot 1$ & $5 \cdot 1$ & $19 \cdot 5$ & 4.6 & $14-3$ & $4 \cdot 2$ & $12 \cdot 6$ & $3 \cdot 3$ \\
\hline Ascorbic acid (mg) & $76 \cdot 8$ & $46 \cdot 9$ & 67.9 & $26 \cdot 2$ & $72 \cdot 2$ & $39 \cdot 5$ & $100 \cdot 9$ & $79 \cdot 0$ \\
\hline \multirow[t]{2}{*}{ Dietary fibre (g) } & $20 \cdot 1$ & $5 \cdot 4$ & $19 \cdot 8$ & $4 \cdot 4$ & $21 \cdot 2$ & $6 \cdot 2$ & $19 \cdot 0$ & $6 \cdot 0$ \\
\hline & \multicolumn{2}{|c|}{ Total } & (b) Wor & $(10)$ & \multicolumn{2}{|c|}{ (14) } & \multicolumn{2}{|c|}{ (7) } \\
\hline Energy (MJ) & $8 \cdot 18$ & 2.08 & $9 \cdot 17$ & 1.90 & $8 \cdot 34$ & $1 \cdot 84$ & 6.42 & 1.92 \\
\hline Protein (g) Animal & 43.9 & $13 \cdot 1$ & $46 \cdot 8$ & $12 \cdot 8$ & $45 \cdot 5$ & 14.8 & $36 \cdot 7$ & $7 \cdot 7$ \\
\hline Total & $67 \cdot 3$ & $15 \cdot 6$ & $71 \cdot 4$ & $16 \cdot 0$ & $69 \cdot 1$ & $15 \cdot 4$ & $57 \cdot 7$ & $12 \cdot 8$ \\
\hline Fat (g) & 89.8 & $27 \cdot 1$ & $101 \cdot 1$ & $27 \cdot 0$ & 90.9 & $24 \cdot 2$ & $71 \cdot 7$ & 26.9 \\
\hline Carbohydrate (g) & $228 \cdot 8$ & $74 \cdot 2$ & $262 \cdot 5$ & $63 \cdot 8$ & $234 \cdot 8$ & $77 \cdot 0$ & $168 \cdot 7$ & $49 \cdot 1$ \\
\hline Sucrose (g) & $56 \cdot 7$ & $32 \cdot 9$ & $72 \cdot 1$ & $29 \cdot 4$ & $60 \cdot 4$ & 33.9 & $27 \cdot 2$ & $13 \cdot 6$ \\
\hline Calcium (mg) & 919 & 272 & 989 & 269 & 967 & 294 & 725 & 124 \\
\hline Iron (mg) & $12 \cdot 3$ & $3 \cdot 0$ & $12 \cdot 3$ & $3 \cdot 4$ & $12 \cdot 4$ & $3 \cdot 0$ & $11 \cdot 7$ & $2 \cdot 7$ \\
\hline Vitamin A $(\mu \mathrm{g})$ & 1547 & 1128 & 1230 & 874 & 1532 & 844 & 2030 & 1796 \\
\hline Thiamin (mg) & 1.05 & 0.26 & 1.06 & 0.29 & 1.07 & 0.25 & 1.00 & 0.27 \\
\hline Riboflavin (mg) & $1 \cdot 67$ & 0.60 & $1 \cdot 70$ & 0.59 & 1.67 & 0.64 & $1 \cdot 60$ & 0.60 \\
\hline Nicotinic Acid (mg) & $12 \cdot 5$ & $3 \cdot 4$ & $12 \cdot 1$ & 3.6 & $13 \cdot 1$ & $3 \cdot 7$ & $12 \cdot 1$ & $2 \cdot 9$ \\
\hline Ascorbic acid (mg) & $75 \cdot 7$ & $34 \cdot 8$ & $73 \cdot 2$ & $36 \cdot 1$ & $77 \cdot 2$ & $40 \cdot 0$ & $76 \cdot 2$ & $24 \cdot 8$ \\
\hline Dietary fibre (g) & $19 \cdot 8$ & $5 \cdot 3$ & $20 \cdot 2$ & 4.9 & $21 \cdot 5$ & $4 \cdot 7$ & 15.8 & $5 \cdot 2$ \\
\hline
\end{tabular}

chips $19 \mathrm{~g}$, non-manual workers). Consumption of wine, spirits and beer was greater for men in the higher classes.

\section{Energy intake}

Total energy intake of the women was significantly less than that of the men (Table 2, $t$ $3.24, P<0.01$ ). Mean energy intakes as a percentage of that suggested as appropriate were $97.5 \pm 23.6$ men, $95.5 \pm 23.9$ women taking into account age and occupation for each individual (Department of Health and Social Security, 1979). Fig. 1 shows that, in general, the energy intakes of women who were trying to control their weight was lower than average. However, two women with a weight problem were consuming 9 and $11 \mathrm{MJ} / \mathrm{d}$. Energy intake in women fell with increasing age (Table 2). There was no effect of weight consciousness nor age on energy intake in men (Fig. 1, Table 2). The difference in energy intake of the thirteen men smokers $(9 \cdot 35 \pm 2 \cdot 71 \mathrm{MJ})$ was not statistically different from non-smokers $(10.35 \pm 2.18 \mathrm{MJ})$. The average energy intakes of manual and non-manual workers were equal.

The average energy intake of the group as a whole was $9 \cdot 11 \pm 2 \cdot 42 \mathrm{MJ}$. When divided 


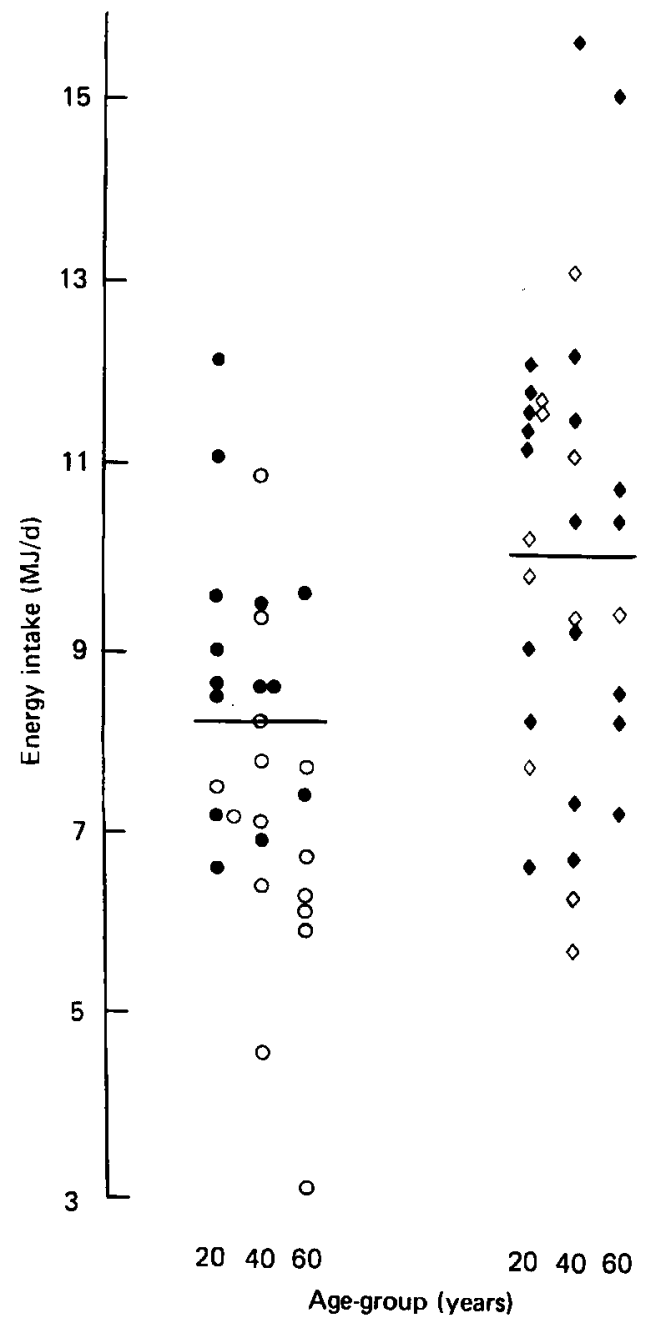

Fig. 1. Individual energy intakes (MJ/d) by sex and age-groups for a randomly chosen group of Cambridgeshire adults. $(\bullet, 0)$, women; $(\diamond, \diamond)$, men; $(0, \diamond)$, subjects with weight problems; $(\bullet$, $\diamond)$, others.

into three time-periods, breakfast and mid-morning snacks (B), lunch and afternoon snacks (L), and evening meals (E), $20 \%$ of the day's total energy intake was taken at B $(1.82 \pm 0.92 \mathrm{MJ}) ; 33 \%$ at $\mathrm{L}(3.01 \pm 0.98 \mathrm{MJ})$ and $47 \%$ at $\mathrm{E}(4.28 \pm 1.40 \mathrm{MJ})$. These differences were highly significant, the $t$ value for B $v$. L was $7 \cdot 06$, for $\mathrm{L} v$. E 5.88 , for B v. E $11.69(P<0.001)$.

\section{Nutrient intake}

Individual protein and fat intakes were closely related to energy intakes $(r 0.77,0.91)$. Again women consumed significantly less than the men $(t 2.19$ (protein), $2 \cdot 10$ (fat), $P<0.05)$ and less with increasing age. As can be seen from their distribution (Fig. 2) the ranges in individual intakes were large; 40-135 $\mathrm{g}$ protein/d, 24-165 $\mathrm{g}$ fat/d.

The range of sucrose intakes (Fig. 3) was large, with some subjects consuming only 5-10 g/d while other subjects took $240 \mathrm{~g} / \mathrm{d}$. Average intakes for women $(55 \mathrm{~g} / \mathrm{d})$ were significantly lower than those for men $(90 \mathrm{~g} / \mathrm{d})(t 3.30, P<0.01)$. The difference in sucrose consumption 


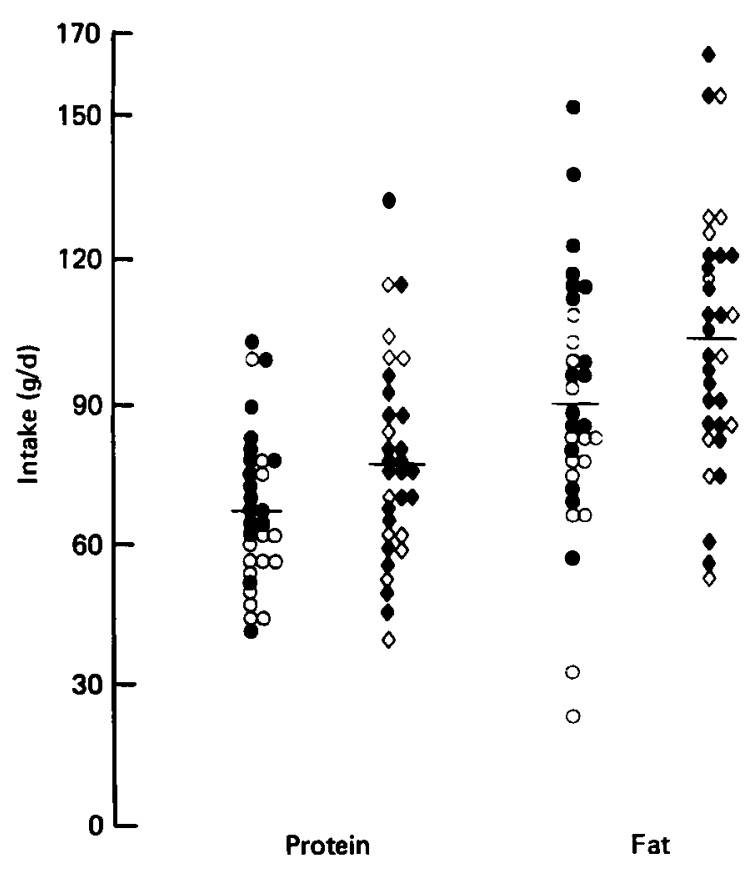

Fig. 2. Individual intakes of protein and fat (g/d) for a randomly-chosen group of Cambridgeshire adults. $(O, O)$, women; $(\diamond, \diamond)$, men; $(O, \diamond)$, subjects with weight problems; $(O, \diamond)$, others.

between male manual and non-manual workers $(102 \cdot 2 \pm 61 \cdot 1,84 \cdot 2 \pm 32 \cdot 5$ respectively) was not significant. Carbohydrate and sucrose intakes were also correlated with energy intake (r $0.90,0.65)$.

There were no significant differences between the sexes in average intakes of other nutrients, with the exception of nicotinic acid equivalents (Table $2, t 3.19, P<0.01$ ). Calculated vitamin $C$ intakes (Fig. 4) were less than the recommended intake of $30 \mathrm{mg}$ in three elderly subjects. Intakes of the subjects surveyed in May were significantly lower than those surveyed in July (May $58.8 \pm 42.9 \mathrm{mg}$, July $98.9 \pm 48.6 \mathrm{mg} ; t 2.47, P<0.05$ ) but not lower than in June and August $(69.1 \pm 24 \cdot 3,75 \cdot 9 \pm 34.0 \mathrm{mg})$. The difference in vitamin $C$ intakes calculated for manual workers $(69.4 \pm 33.0 \mathrm{mg})$ and non-manual workers $(90 \cdot 2 \pm 54 \cdot 2 \mathrm{mg})$ was not significant, and neither were the differences in iron and riboflavin intakes.

All individuals who had consumed liver during the survey week were at the top-end of the distribution in calculated vitamin $A$ intakes (Fig. 5), and their average intake was $3454 \pm 1612 \mu \mathrm{g}$, compared with $985 \pm 467 \mu \mathrm{g}$ in the other $(t 9.49, P<0.001)$. Differences in average intakes of vitamin $A$ between the social classes and at different months of the survey were not significant.

Total daily water intake was $2064 \pm 710 \mathrm{~g}$, of which $1257 \mathrm{~g}$ was taken as water, soft drinks, tea, coffee, alcoholic drink and soup.

\section{Dietary fibre intakes}

Total dietary fibre intakes by sex and 20-year age-group are shown in Table 2; the distribution of individual intakes and sources of dietary fibre have been discussed elsewhere (Bingham et al. 1979). Individual dietary fibre intakes were related to energy intakes ( $r 0.57)$ 

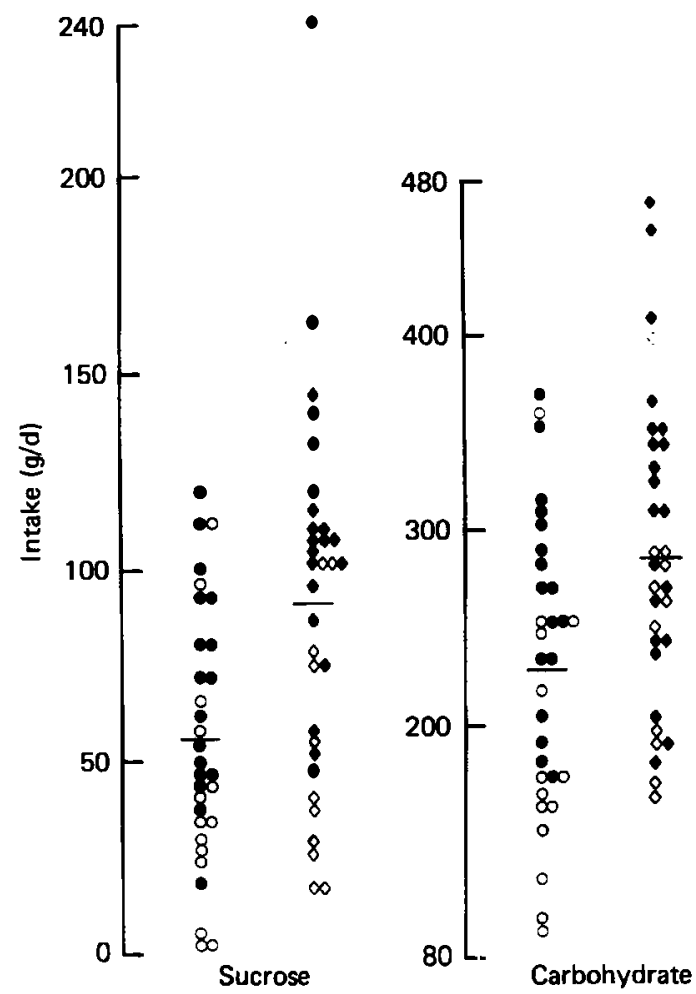

Fig. 3. Individual intakes of sucrose and carbohydrate (g/d) for a randomly-chosen group of Cambridgeshire adults. $(0,0)$, women; $(\diamond, \diamond)$, men; $(0, \diamond)$, subjects with weight problems; $(0$, $\bullet$ ), others.

Table 3. Anthropometric results for a randomly-chosen group of Cambridgeshire adults by sex, social class (men), and claim to have a weight problem (women)

(Mean values and standard deviations, ranges in parentheses)

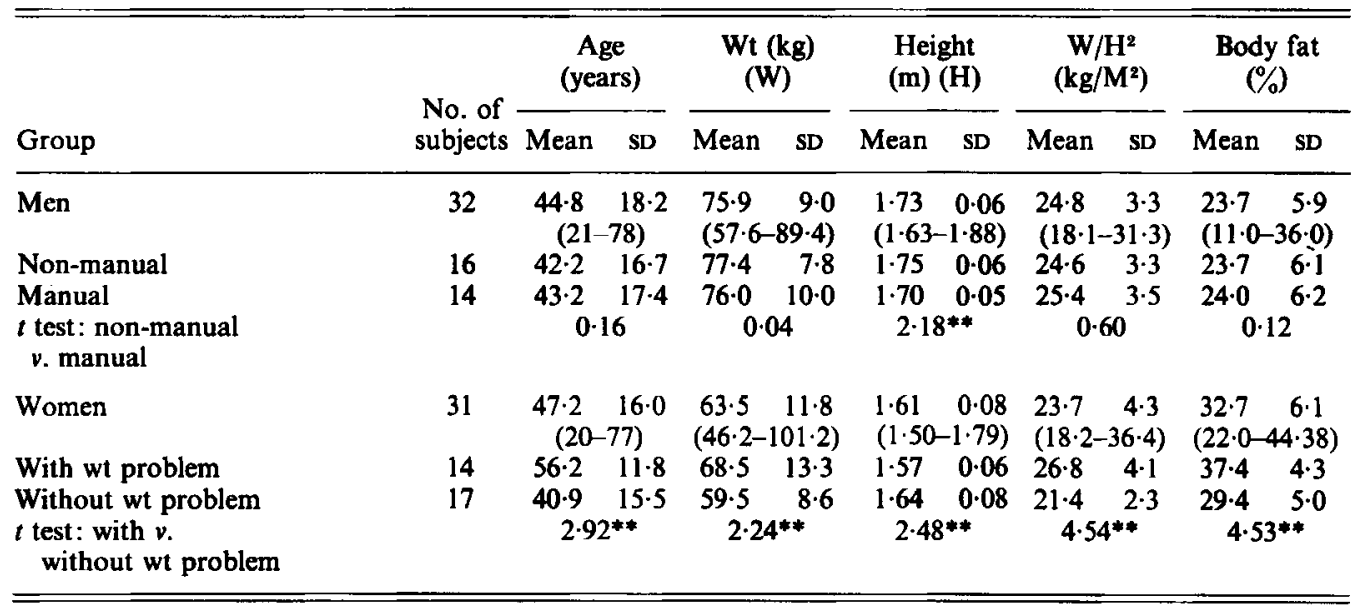

*** $P<0.05$. 


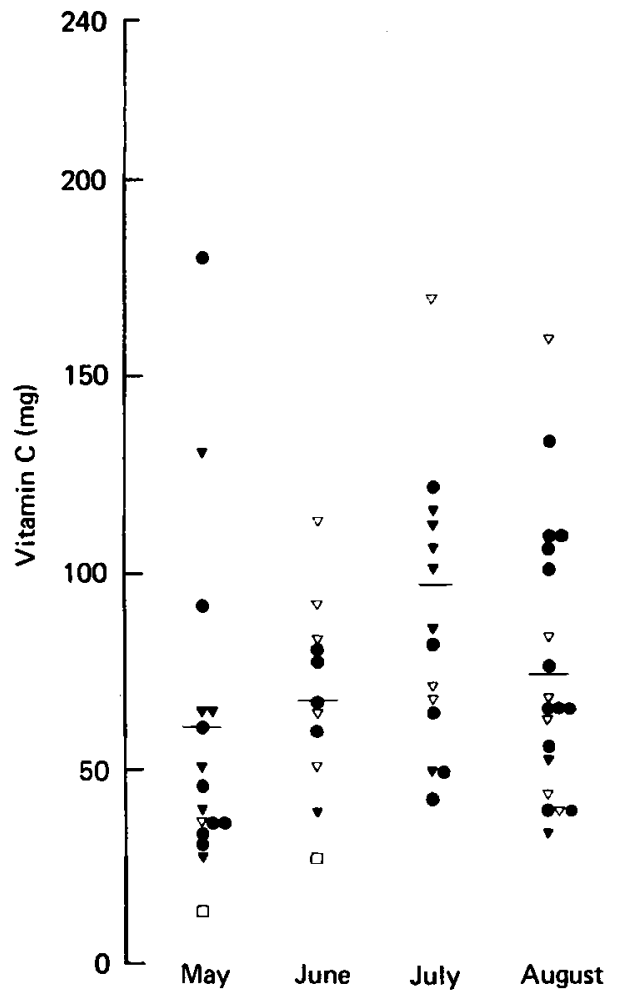

Fig. 4. Individual intakes of vitamin $C$ in each of the four months of the survey (mg/d) for a randomly-chosen group of Cambridgeshire adults. $(\Theta)$, women; $(\nabla)$, men, manual workers; $(\nabla)$, men, non-manual workers; ( $\square$ ), men, unclassified.

so that the average fibre intake of the subjects with weight problems was significantly lower $(18.2 \pm 5.9 \mathrm{~g})$ than the others $(21.4 \pm 4.4 \mathrm{~g} ; t 2.46, P<0.02)$.

Total dietary fibre intakes $(\mathrm{g})$ were significantly lower in May than in June (16.9 $\pm 5 \cdot 5$, $21.8 \pm 4 \cdot 7 ; t 2 \cdot 37, P<0.05$ ), but not than in July or August $(20.9 \pm 5.8,20.8 \pm 4 \cdot 2)$ (Fig. 6). Total dietary fibre intake $(\mathrm{g})$ of the social classes was similar (manual 19.9 $\pm 4 \cdot 8$, non-manual $21 \cdot 5 \pm 5 \cdot 5)$.

\section{Anthropometry}

Male non-manual workers were $0.05 \mathrm{~m}$ taller on average than the manual workers $\left(P<0.05\right.$; Table 3 ), but no significant difference in age, weight, $\mathrm{W} / \mathrm{H}^{2}$ or body fat was detected between the two groups. Each group contained six smokers. No significant difference was detected in age, weight, height, $\mathrm{W} / \mathrm{H}^{2}$, or percentage body fat between the men who smoked or had weight problems and those who did not. Women who had weight problems were on average $0.067 \mathrm{~m}$ shorter, $9.0 \mathrm{~kg}$ heavier and 15 years older than those who did not.

Table 4 shows mean $\mathrm{W} / \mathrm{H}^{2}$ and percentage body fat by age and sex. Men reached their peak weight in middle age, whereas in women both $\mathrm{W} / \mathrm{H}^{2}$ and percentage body fat rose progressively with age. If over-weight is defined as greater than $110 \%$ of the upper range of $\mathrm{W} / \mathrm{H}^{2}$ for a medium frame, 45 and $40 \%$ respectively of the men and women were overweight.

There was no marked association between height, weight and obesity index with energy 
Table 5. Changes in $W / H^{2}$ and $\%$ body fat with age in a randomly chosen group of Cambridgshire adults

\begin{tabular}{|c|c|c|c|c|c|c|}
\hline \multirow[b]{2}{*}{ Age-group (years) } & \multicolumn{3}{|c|}{ 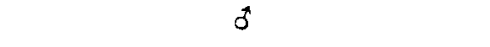 } & \multicolumn{3}{|c|}{$q$} \\
\hline & $20-39$ & $40-59$ & $60-79$ & 20-39 & $40-59$ & $60-80$ \\
\hline $\begin{array}{l}\text { No. of subjects } \\
\text { W/H } \\
\text { Bodyfat }(\%)\end{array}$ & $\begin{array}{c}13 \\
23 \cdot 3 \pm 3 \cdot 2 \\
19 \cdot 0 \pm 3 \cdot 8\end{array}$ & $\begin{array}{c}12 \\
26 \cdot 3 \pm 2 \cdot 9 \\
27 \cdot 5 \pm 4 \cdot 4\end{array}$ & $\begin{array}{c}7 \\
25 \cdot 4 \pm 3.4 \\
26 \cdot 6 \pm 5 \cdot 6\end{array}$ & $\begin{array}{c}9 \\
21 \cdot 9 \pm 3 \cdot 2 \\
27.9 \pm 3.6\end{array}$ & $\begin{array}{c}14 \\
24 \cdot 3 \pm 5 \cdot 1 \\
33 \cdot 9 \pm 6 \cdot 4\end{array}$ & $\begin{array}{c}8 \\
25 \cdot 1 \pm 2 \cdot 8 \\
36 \cdot 5 \pm 4 \cdot 7\end{array}$ \\
\hline
\end{tabular}

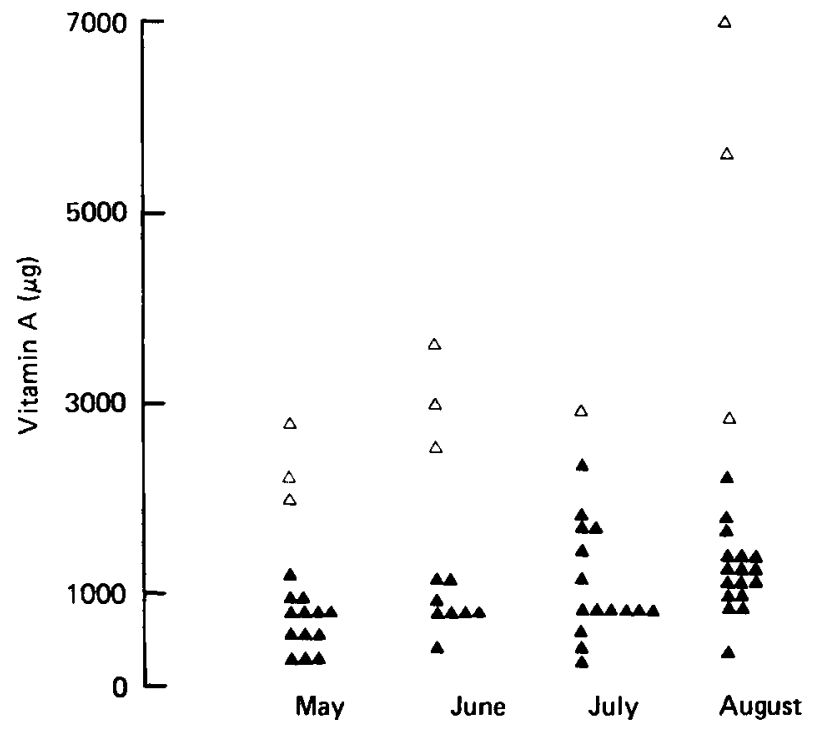

Fig. 5. Individual intakes of vitamin $A$ in each of the four months of the survey $(\mu \mathrm{g} / \mathrm{d})$ in a randomlychosen group of Cambridgeshire adults. $(\Delta)$, subjects who consumed liver during the survey; $(\Delta)$, others.

intake, nor with dietary fibre, dietary fibre/MJ, and dietary fat, even when the sexes and those without weight problems were considered separately.

\section{DISCUSSION}

The cumulative method of weighing and recording food intake was easily understood by the subjects and did not inconvenience them to any marked extent. Written instructions were kept to a minimum and detailed information was gathered only after the subjects had grasped the essentials of the technique. Co-operation rates in this randomly-selected population sample were unaffected by social-class bias (Bingham et al. 1979) and similar to those of surveys where other less demanding methods, for example, the dietary history, have been used (Marr, 1971).

The results show large ranges in the intake of almost every nutrient. Possible contributors are chance variation, which might account for $50 \%$ or more of the difference in nutrient intake from one person to another in any 1 week (Yudkin, 1951), and inadequacies in the method used to assess dietary intake. The weighed inventory, however, is thought to be one of the most accurate ways of assessing food intake (Marr, 1971).

Mean energy intake was very similar to that suggested in 1979 (Department of Health and Social Security, 1979) and corresponds with the decline in national energy intakes 


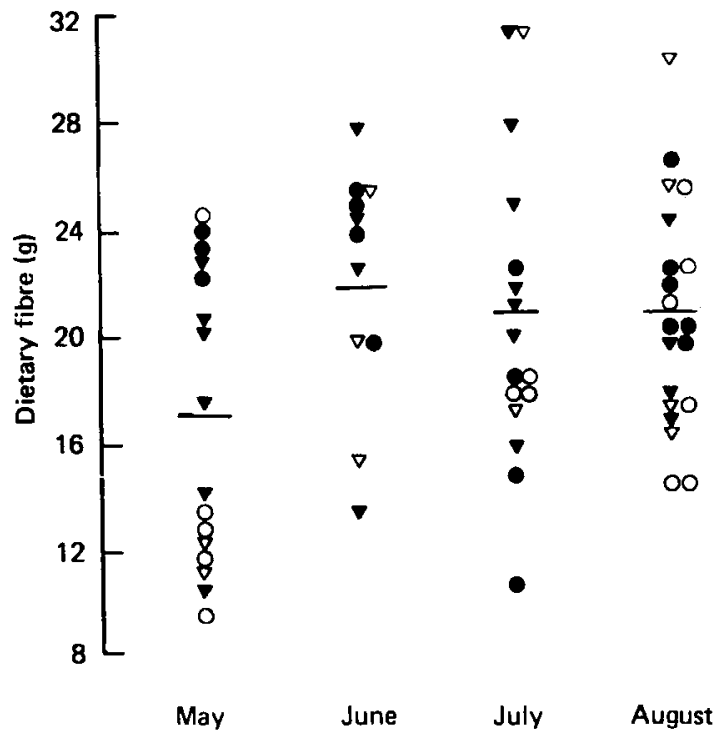

Fig. 6. Individual intakes of total dietary fibre in each of the four months of the survey $(\mathrm{g} / \mathrm{d})$ in a randomlychosen group of Cambridgeshire adults. $(0,0)$, women; $(\diamond, \diamond)$, men; $(0, \diamond)$, subjects with weight problems; $(\Theta, \bullet)$, others.

measured by the National Food Survey that has occurred over the past decade (10.8 MJ, $1969,9 \cdot 5 \mathrm{MJ}, 1977)$. In 1971 , the energy intake of adolescents had also fallen by $9 \%$ since 1964 (Durnin et al. 1974). One interpretation of this fall is that energy expenditure and thereby intake has decreased in the population as a whole. Ownership of appliances that reduce energy expenditure, such as home central-heating systems and motor cars, has increased over this period (Office of Population Censuses and Surveys, 1973, 1978; Department of Transport, 1979). In young men, alcoholic drinks supplied a substantial proportion of their daily energy intake (1.0 MJ or $9 \%$ of the total energy). However, average consumption for the group as a whole was lower than expected from Customs and Excise information (Ministry of Agriculture, Fisheries and Food, 1979) even when regional variation in spending on alcoholic drink is taken into account (Department of Employment, 1979).

Part of the range in distribution of total energy intakes (Fig. 1) was due to people who were trying to lose weight or were following a medically-prescribed diet. The low energy intake of these individuals, particularly women, contributes significantly to the low average energy intake of the population studied here. A similar alteration in the distribution of energy intake in the British population as a whole, in which at least $20 \%$ of adults attempt to lose weight each year (Butterfield, 1975) would further explain the decline in national average energy intakes over the past decade. Nevertheless, despite a diet which is probably lower in energy than in previous decades, $45 \%$ of the men and $40 \%$ of the women were overweight and we are impressed with the extent to which these British adults had difficulty in remaining lean. The trends with age in Quetelet index (Table 4) were similar to those observed elsewhere (Department of Health and Social Security and Medical Research Council, 1976).

Coefficients of variation for individual nutrients (Table 2 and Figs. 1-6) generally varied from 25 to $30 \%$. Since the survey was spread over 4 months, seasonal effects made the coefficient of variation in vitamin $\mathrm{C}$ consumption larger $(52 \%)$ as noted in the National Food Survey (Ministry of Agriculture, Fisheries and Food, 1979). Total dietary fibre intakes 
were lowest in May (Fig. 6) presumably because the supply of fresh fruit and vegetables, which are the main source of fibre in the UK diet, was at its lowest at this time of year, particularly of home-produced varieties. Seasonal changes in food intake, however, only partly accounted for differences between individuals. This was a small study and although differences were noted in energy intake between smokers and non-smokers and in nutrient and fibre intake between manual and non-manual social classes, they were not statistically significant. The variability in individual intake of nutrients cannot thus be attributed to these factors in this population, and a more important factor controlling nutrient consumption was total energy intake. With the exception of vitamins $C$ and $A$ the intake of all nutrients showed a significant association $(r>0.33, P<0.01)$ with energy intake e.g. energy and protein intake $r 0.77$, energy and fat intake $r 0.91$.

Over all in this study $40 \%$ of energy intake came from fat, $13 \%$ from protein, $13 \%$ from sucrose and only approximately $26 \%$ from starch. Consumption of dietary fibre was low. When information from individuals is available, however, it is clear that within a population many people consume diets containing amounts of fat, sugar and fibre that could be considered highly injurious to health if epidemiological and other studies are taken into account. For example, the percentage of total energy derived from fat ranged from $27-54 \%$ (mean \pm SD $40 \cdot 2 \% \pm 4 \cdot 3$ ). These variations in total fat intake and the proportion of energy coming from fat are similar to variations observed internationally and which are associated with widely-varying risks of diseases such as cancer and heart disease (Armstrong \& Doll, 1975; Keys, 1970). There is therefore ample scope for change in the British diet both on average and for the individual, in line with recent recommendations (Passmore et al. 1979; United States Senate, 1977).

The authors are greatly indebted to those of the village, and their relatives, who made the study possible by agreeing to undertake the weighing of their food. They also thank $\mathrm{Mr}$ R. Tibbs of the Cambridge Evening News and the village organisations for publicizing the survey, and Dr D. Lewis for his help. Miss T. Breacker, T. Cole and K. Day gave valuable help with the dietary analysis and Dr David Southgate kindly made available much unpublished information on the fibre content of food.

\section{REFERENCES}

Armstrong, B. K. \& Doll, R. (1975). Int. J. Cancer 15, 617.

Armstrong, B. K., Mann, J. I., Adelstein, A. M. \& Eskin, F. (1975). J. Chron. Dis. 28, 455.

Bingham, S., Cummings, J. H. \& McNeil, N. I. (1979). Am. J. clin. Nutr. 32, 1313.

Burkitt, D. P., Walker, A. R. P. \& Painter, N. S. (1972). Lancet ii, 1408.

Butterfield, W. J. H. (1975). Rec. Adv. Obesity Res. 1, 9.

Department of Employment (1979). Family Expenditure Surveys, 1977, London: H.M. Stationery Office.

Department of Health and Social Security (1979). Rep. Pub. Hlth. med. Subj. no. 120.

Department of Health and Social Security and Medical Research Council (1976). Research on obesity. London: H. M. Stationery Office.

Department of Transport (1979). Transport Statistics of Great Britain 1967-77. London: H.M. Stationery Office.

Disselduff, M. M., Marr, J. W. \& Robertson, J. (1968). Food Composition Tables London: Department of Health and Social Security.

Durnin, J. V. G. A., Lonergan, M. E., Good, J. \& Ewan, A. (1974). Br. J. Nutr. 32, 169.

Durnin, J. V. G. A. \& Womersley, J. (1974). Br. J. Nutr. 32, 77.

Keys, A. (1970). Circulation 41-42, Supplement.

McCance, R. A. \& Widdowson, E. M. (1960). Med. Res. Counc. Spec. Rep. Ser, no. 297.

Marr, J. W. (1971). Wld Rev. Nutr. Diet. 13, 105.

Medical Research Council (1945). Med. Res. Counc. (War) Memo, no. 14.

Ministry of Agriculture, Fisheries and Food (1979). Annual Report of the National Food Survey Committee. London: H.M. Stationery Office.

Morris, J. N., Marr, J. W. \& Clayton, D. G. (1977). Br. Med. J. 2, 1307.

Office of Population Censuses and Surveys (1970). Classification of Occupations. London: H.M. Stationery Office. 
Office of Population Censuses and Surveys (1973). General Household Survey, 1971. London: H.M. Stationery Office.

Office of Population Censuses and Surveys (1978). General Household Survey, 1976. London: H.M. Stationery Office.

Office of Population Censuses and Surveys (1978). D. S. no. 1 The Registrar General's Decennial Supplement for England and Wales, 1970-72. London: H.M. Stationery Office.

Passmore, R., Hollingsworth, D. F. \& Robertson, J. (1979). Br. med. J. 1, 527.

Southgate, D. A. T. (1978). Am. J. clin. Nutr. 31, Suppl. S107.

Southgate, D. A. T., Bailey, B., Collinson, E. \& Walker, A. F. (1976). J. Hum. Nutr. 30, 303.

United States Senate (1977). Dietary Goals for the United States. Washington DC: US Government Printing Office.

Widdowson, E. M. (1936). J. Hyg. 36, 269.

Yudkin, J. (195I). Br. J. Nutr. 5, 177. 